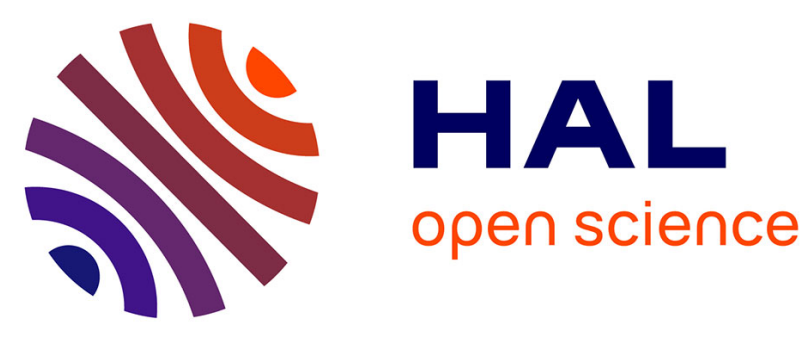

\title{
Sustained increase of alpha7 nicotinic receptors and choline-induced improvement of learning deficit in STOP knock-out mice.
}

Caroline Bouvrais-Veret, Stéphanie Weiss, Annie Andrieux, Annie Schweitzer, J Michael Mcintosh, Didier Job, Bruno Giros, Marie-Pascale Martres

\section{To cite this version:}

Caroline Bouvrais-Veret, Stéphanie Weiss, Annie Andrieux, Annie Schweitzer, J Michael Mcintosh, et al.. Sustained increase of alpha7 nicotinic receptors and choline-induced improvement of learning deficit in STOP knock-out mice.. Neuropharmacology, 2007, 52 (8), pp.1691-700. 10.1016/j.neuropharm.2007.03.015 . inserm-00379958

\section{HAL Id: inserm-00379958 https://www.hal.inserm.fr/inserm-00379958}

Submitted on 5 May 2009

HAL is a multi-disciplinary open access archive for the deposit and dissemination of scientific research documents, whether they are published or not. The documents may come from teaching and research institutions in France or abroad, or from public or private research centers.
L'archive ouverte pluridisciplinaire HAL, est destinée au dépôt et à la diffusion de documents scientifiques de niveau recherche, publiés ou non, émanant des établissements d'enseignement et de recherche français ou étrangers, des laboratoires publics ou privés. 
Sustained increase of alpha7 nicotinic receptors and choline-induced improvement of learning deficit in STOP knock-out mice.

Caroline Bouvrais-Verett ${ }^{1,2 *}$, Stéphanie Weiss ${ }^{1,2 *}$, Annie Andrieux ${ }^{3}$, Annie Schweitzer ${ }^{3}$, J. Michael McIntosh ${ }^{4}$, Didier Job ${ }^{3}$, Bruno Giros ${ }^{1,2}$ and MariePascale Martres ${ }^{1,2 \#}$

*equal contribution

${ }^{1}$ Inserm, U513, Laboratoire de Neurobiologie et Psychiatrie, Créteil, F-94000 France; ' ${ }^{2}$ Univ Paris 12, Créteil, F-94000 France. ${ }^{3}$ Inserm, U366, Laboratoire du Cytosquelette, CEA, Grenoble, F-38000 France. ${ }^{4}$ Department of Psychiatry, University of Utah, Salt Lake City, UT 84112

Running title: Nicotinic transmission in STOP KO mice

Keywords: cytoskeleton, dopamine, locomotion, cued version of the water maze, schizophrenia, vesicular acetylcholine transporter/nicotinic receptors

Footnote: For nAChRs, * indicates the association with other subunits

\#Address correspondence to Marie-Pascale Martres, Inserm U513, Laboratoire de Neurobiologie et Psychiatrie, Faculté de Médecine, 8 rue du Général Sarrail, Créteil, F-94010 France. Tel: (33) 149813 658; Fax: (33) 149813 685; E-mail: Marie-Pascale.Martres@creteil.inserm.fr. 


\section{ABSTRACT}

Mice deficient in the microtubule stabilizing protein STOP (Stable Tubule Only Polypeptide) show synaptic plasticity anomalies in hippocampus, dopamine hyper-reactivity in the limbic system and severe behavioral deficits. Some of these disturbances are alleviated by long-term antipsychotic treatment. Therefore, this mouse line represents a pertinent model for some aspects of schizophrenia symptomatology. Numerous data support dysfunction of nicotinic neurotransmission in schizophrenia and epidemiological studies show increased tobacco use in schizophrenic patients, in whom nicotine has been reported to improve cognitive deficits and impairment in sensory gating.

In this study, we examined potential alterations in cholinergic ( $A C h)$ and nicotinic components and functions in STOP mutant mice. STOP KO mice displayed no variation of the density of $A C h$ esterase and $\beta 2^{\star}$ nicotinic receptors ( $n A C h R s$ ), large reductions in the density of vesicular $A C h$ transporter and $\alpha 6^{*} \mathrm{nAChRs}$ and marked increases in the density of $\alpha 7 \mathrm{nAChRs}$, in some brain areas. STOP KO mice were hypersensitive to the stimulating locomotor effect of nicotine and, interestingly, their impaired performance in learning the cued version of the water maze were improved by administration of the preferential $\alpha 7$ nAChR agonist choline.

Altogether, our data show that the deletion of the ubiquitous STOP protein elicited restricted alterations in ACh components. They also suggest that nicotinic neurotransmission can be deficient in STOP KO mice and that mutant mice can represent a meaningful model to study some nicotinic dysfunctions and therapeutic treatments. 


\section{INTRODUCTION}

Neuronal microtubules play a structural key role in morphogenesis and protein transports in dendrites and axons. Recently, microtubules and their effectors, such as microtubule-associated proteins (MAP1B, STOP) and sequestering proteins, have been implicated in synaptic plasticity (Bosc et al., 1996; Guillaud et al., 1998; van Rossum and Hanisch, 1999). STOP knock-out (KO) mice exhibit synaptic abnormalities in the hippocampus, including depleted glutamatergic vesicle pools, decreased long-term potentiation and depression (Andrieux et al., 2002) and decreased mRNA transcripts of synaptic proteins (e.g. synaptophysin, GAP-43 and spinophilin; Eastwood et al., 2006). These mice show severe behavioral deficits, such as purposeless and disorganized activity, impaired social interactions and maternal behavior, deficits in prepulse inhibition (PPI) of the startle reflex and hypersensitivity to mild stress and to the stimulant locomotor effect of amphetamine (Andrieux et al., 2002; Brun et al., 2005; Fradley et al., 2005). STOP KO mice also display dopamine (DA) hyperreactivity in the limbic system (Brun et al., 2005). Whereas basal extracellular $D A$ levels are not modified in the striatum and the nucleus accumbens of mutant mice, electrically evoked DA release is selectively increased in the nucleus accumbens of STOP KO mice. Importantly, some of these dysfunctions can be alleviated by chronic antipsychotic drug treatment (Andrieux et al., 2002; Brun et al., 2005). Therefore, STOP KO mice may represent a useful experimental model for studying several features of schizophrenia, a notion consistent with recent models implicating synaptic disorders in the etiology of schizophrenia (Mirnics et al., 2001; Frankle et al., 2003). The pertinence of this experimental mouse line is strengthened by recent studies showing an association between schizophrenia and polymorphisms in the MAP6 gene, the human homolog of STOP gene (Shimizu et al., 2006).

Numerous data implicate nicotinic neurotransmission dysfunction in several psychiatric disorders, including schizophrenia. Indeed, post-mortem studies show decreased number of nicotinic receptors in various brain areas of schizophrenic patients (Freedman et al., 1995; Breese et al., 2000; Mihailescu and Drucker-Colin, 2000). Moreover, linkage studies strongly suggest that the P50 auditory sensory deficit in schizophrenia is linked to the $\alpha 7$ nicotinic receptor gene (Freedman et al., 1997; Leonard et al., 2002). In addition, epidemiological studies show a 2-3 fold increase in tobacco use in schizophrenic patients (Glassman, 1993; de Leon et al., 1995). It has been suggested that nicotine serves as a self-medication to improve a number of cognitive deficits associated with schizophrenia, to enhance the therapeutic effect of antipsychotics, to alleviate negative symptoms and/or to reduce the sideeffects of antipsychotic drugs (Kumari and Postma, 2005). Thus, deficits in 
sensorimotor gating, often encountered in schizophrenic patients and their first-degree relatives, is alleviated by nicotine, probably via its action through hippocampal $\alpha 7$ nicotinic receptors (Freedman et al., 1997; Adler et al., 1998; Leonard et al., 2002).

Thus, STOP KO mice, which serve as a pertinent experimental model for some schizophrenic related symptoms, present an opportunity to characterize key components of the cholinergic/nicotinic neurotransmission. We first measured the density of acetylcholine esterase ( $A C h E)$, of vesicular $A C h$ transporter (VAChT) and of $\beta 2^{\star}, \alpha 6^{*}$ and $\alpha 7$ nicotinic receptors (nAChR) in various brain areas of wild-type (WT) and STOP KO mice. Then, in order to evaluate the potential consequences of the modified expression of cholinergic/nicotinic markers, we chose to characterize two behaviors that involved nicotinic neurotransmission, namely nicotine-induced locomotor activity and mouse learning in the Morris water maze. 


\title{
MATERIALS AND METHODS
}

\begin{abstract}
ANIMALS
Homozygous STOP KO mice and their WT littermates were obtained from the intercross (F2) of heterozygous 50:50 BALBc/129 SvPas-F1 mice (Andrieux et al., 2002). The genotype of the mice was determined from tail biopsies as previously described (Andrieux et al., 2002). Animals were housed four to six per cage by gender and litter. They were kept under standard conditions, i.e., laboratory chow and water available ad libitum, temperature at $23 \pm 2{ }^{\circ} \mathrm{C}$, humidity at $55 \pm 10 \%$ and a light cycle of $12 \mathrm{~h}$ light:12 h dark (lights on at 7:30 a.m.). Experiments were carried out in accordance with the European Communities Council directive (86/809/EEC) and approved by the local ethical committee. Mice were allowed to habituate to the animal holding room for at least one week prior to use. All experiments were conducted on naive WT and KO mice from the same litters (about 60\%/40\% females/males), three to four months old.
\end{abstract}

\section{DRUGS}

Nicotine bitartrate and choline hydrochloride were purchased from Sigma-Aldrich (St Louis, MO). Drugs were dissolved in physiological saline as free bases and were administered sub-cutaneously in a volume of $100 \mu$ per $20 \mathrm{~g}$ weight. $\left[{ }^{125} \mathrm{I}\right]$-Epibatidine $(74 \mathrm{TBq} / \mathrm{mmol})$ and (3-[ $\left.{ }^{125} \mathrm{I}\right]$-iodotyrosyl) $\alpha$-bungarotoxin (74 TBq/mmol) were from GE Healthcare. $\left[{ }^{125} \mathrm{I}\right]-\alpha$-ConotoxinMII was synthesized as previously described (Whiteaker et al., 2000). Before use, rabbit $\left[{ }^{125} \mathrm{I}\right]-$ Ig $F\left(a b^{\prime}\right) 2$ fragment antibodies (28-111 TBq/mmol, GE Healthcare, Orsay, France) were purified by gel filtration onto a PD10 column (Sephadex $625 \mathrm{M}$, Pharmacia) in PBS (50 $\mathrm{mM} \mathrm{NaH}{ }_{2} \mathrm{PO}_{4} / \mathrm{Na}_{2} \mathrm{HPO}_{4}, 154 \mathrm{mM} \mathrm{NaCl}$ ) containing $0.1 \%$ gelatin. The first $0.25 \mathrm{ml}$ eluate was discarded and the following $3.5 \mathrm{ml}$ eluate was put into $400 \mathrm{ml}$ PBS supplemented with $3 \%$ bovine serum albumin (BSA), $1 \%$ goat serum, $1 \mathrm{mM} \mathrm{NaI}$ and $0.02 \%$ sodium azide. This solution was kept at $4^{\circ} \mathrm{C}$, for four to six weeks.

\section{QUANTITATIVE AUTORADIOGRAPHY}

Mice were killed by cervical dislocation (between 10:00 a.m. and 4:00 p.m.) and their brains rapidly removed and frozen in isopentane at $-30^{\circ} \mathrm{C}$. Serial $10 \mu \mathrm{m}$ coronal sections were cut at $-20^{\circ} \mathrm{C}$, thaw-mounted on Superfrost Plus ${ }^{\circledR}$ slides and stored at $-80^{\circ} \mathrm{C}$ until use. Coronal levels used are IA $=4.90-5.22 \mathrm{~mm}$ for the nucleus accumbens and the striatum, IA=1.86-2.22 $\mathrm{mm}$ for the dorsal hippocampus and IA=0.52-0.72 $\mathrm{mm}$ for the substantia nigra and the ventral tegmental area. 


\section{Immunoautoradiography of acetylcholine esterase (AChE) and vesicular acetylcholine transporter (VAChT)}

Brain sections were fixed with $4 \%$ paraformaldehyde for 15 min at room temperature, extensively washed with PBS and then incubated for $1 \mathrm{~h}$ at room temperature in PBS containing 3\% BSA, $1 \%$ goat serum and $1 \mathrm{mM} \mathrm{NaI}$. Sections were incubated for $2 \mathrm{~h}$ at room temperature (or overnight at $4^{\circ} \mathrm{C}$ ) in the presence of $A C h E$ antiserum (1:1,000 dilution, polyclonal $A C h E$ antibody characterized by Marsh et al., 1984) or VAChT antiserum (1:8,000 dilution; polyclonal antibody directed against mouse VAChT Ser ${ }^{478}-\operatorname{Ser}^{530}$ peptide). After washes, slides were incubated for $2 \mathrm{~h}$ at room temperature with purified antirabbit [ $\left.{ }^{125} \mathrm{I}\right]-\mathrm{Ig} G$ (370-740 MBq/100 $\mathrm{ml}$ ). Sections were extensively washed with PBS, dried and exposed to Biomax MR films for 1-4 days.

\section{Autoradiographic determination of $\beta 2^{*}, \alpha 6^{*}$ and $\alpha 7$ nicotinic receptor densities}

To rule out possible binding of endogenous acetylcholine to nicotinic receptors, sections were pre-incubated in buffer before addition of radioactive ligands.

Labelling of $\beta 2^{\star}$ subunits was performed according to Perry and Kellar (1995). Slides were pre-incubated three times for $5 \mathrm{~min}$ at room temperature in $50 \mathrm{mM}$ Tris- $\mathrm{HCl}$ buffer, $\mathrm{pH} 7.4$, containing $120 \mathrm{mM} \mathrm{NaCl}, 5 \mathrm{mM} \mathrm{KCl}, 2 \mathrm{mM} \mathrm{CaCl} 2$ and $1 \mathrm{mM} \mathrm{MgCl} 2$ (Tris-ions buffer). Sections were incubated for $40 \mathrm{~min}$ at room temperature in the same fresh buffer, in the presence of $0.4 \mathrm{nM}\left[{ }^{125} \mathrm{I}\right]-$ epibatidine with or without $300 \mu \mathrm{M}$ nicotine to determine non-specific binding. Slides were then washed twice for $5 \mathrm{~min}$ in Tris-ions buffer at $4{ }^{\circ} \mathrm{C}$, dipped in ice-cold water, dried and exposed to Biomax MR films for 2-3 days.

Labelling of $\alpha 6^{*}$ subunits was performed according to Whiteaker et al. (2000). Slides were pre-incubated for $15 \mathrm{~min}$ at room temperature in $20 \mathrm{mM}$ HEPES buffer, $\mathrm{pH} 7.5$, containing $144 \mathrm{mM} \mathrm{NaCl}, 1.5 \mathrm{mM} \mathrm{KCl}, 2 \mathrm{mM} \mathrm{CaCl}, 1 \mathrm{mM}$ $\mathrm{MgSO}_{4}$ (standard binding buffer), supplemented with $0.1 \% \mathrm{BSA}$ and $1 \mathrm{mM}$ phenylmethylsulfonyl fluoride. They were incubated in the presence of $0.8 \mathrm{nM}$ $\left.{ }^{125} \mathrm{I}\right]$ - $\alpha$-conotoxin-MII for $2 \mathrm{~h}$ at room temperature in standard binding buffer supplemented with $0.1 \%$ BSA, $5 \mathrm{mM}$ EDTA, $5 \mathrm{mM}$ EGTA and $1 \mathrm{mg} / 100 \mathrm{ml}$ of aprotinin, leupeptin and pepstatin $A$ (protease inhibitors). Non-specific binding was determined in the presence of $1 \mu \mathrm{M}$ epibatidine. Slides were washed for 30 $\mathrm{sec}$ at room temperature and then at $4^{\circ} \mathrm{C}$ in standard binding buffer plus $0.1 \%$ BSA. Afterwards, sections were washed twice for $5 \mathrm{sec}$ at $4^{\circ} \mathrm{C}$ in standard binding buffer with $0.01 \% \mathrm{BSA}$ and, finally, twice for $5 \mathrm{sec}$ at $4^{\circ} \mathrm{C}$ in $5 \mathrm{mM}$ HEPES buffer $\mathrm{pH}$ 7.5. After dipping in ice-cold water and drying, they were exposed to Biomax MR films for 24-72 $\mathrm{h}$. 
Labelling of $\alpha 7$ nicotinic receptors was performed according to Spurden et al. (1997). The slides were pre-incubated for $30 \mathrm{~min}$ at room temperature in $50 \mathrm{mM}$ Tris- $\mathrm{HCl}$ buffer, $\mathrm{pH} 7.4$, containing $0.1 \%$ BSA. Sections were next incubated for $2 \mathrm{~h}$ at room temperature in the same buffer in the presence of $0.5 \mathrm{nM}\left[{ }^{125} \mathrm{I}\right]$ - $\alpha$-bungarotoxin, with or without $1 \mathrm{mM}$ nicotine to determine nonspecific binding. Slides were then washed four times for $10 \mathrm{~min}$ in ice-cold Tris$\mathrm{HCl}$ buffer, dipped in ice-cold water, dried and exposed to Biomax MR films for 1 week.

\section{Quantification of autoradiographic labelling}

Standard radioactive-microscales (GE Healthcare) were exposed on each autoradiographic film to ensure that labelling densities were in the linear range. The autoradiograms were scanned and densitometry was performed with $M C I D^{T M}$ analysis software. Values were expressed in $\mathrm{nCi} / \mathrm{mg}$ and, after subtraction of non-specific labelling, specific densities of four sections per area were averaged for each mouse.

\section{BEHAVIORAL STUDIES}

\section{Locomotor activity}

The horizontal (locomotion) and vertical (rearing) activities were individually assessed in transparent activity cages $(20 \times 15 \times 25 \mathrm{~cm})$, with automatic monitoring of photocell beam breaks, located at $1.5 \mathrm{~cm}$ (horizontal activity) and $6.5 \mathrm{~cm}$ (vertical activity) above the floor (Imetronic, Bordeaux, France). For the dose-response analysis of nicotine and choline, locomotor activities of mice were recorded for $60 \mathrm{~min}$ immediately after sub-cutaneous drug administration, between 9:00 a.m. and 2:00 p.m.

\section{Cued version of the water maze}

The water maze consists of a circular stainless steel pool $(150 \mathrm{~cm}$ diameter, $29 \mathrm{~cm}$ height) filled to a depth of $16 \mathrm{~cm}$ with water at $20-22{ }^{\circ} \mathrm{C}$ and made opaque using a white aqueous emulsion (Acusol $\circledast$ OP 301 opacifier, Rohm Ihaas, France). The pool was located in a sound-attenuated and brightly illuminated room. A video tracking system, including an overhead camera connected to an image analyzer and a computer (View Point, France), was used to monitor activity. Mice were trained to find and escape onto a rough stainless steel platform ( $9 \mathrm{~cm}$ diameter), submerged one $\mathrm{cm}$ below the water surface and made visible by a small contrasted ball ( $4.5 \mathrm{~cm}$ diameter) fixed $11 \mathrm{~cm}$ above the platform. The pool was surrounded by curtains to hide other spatial cues. Both the platform location and the animal starting position were pseudo-randomly changed for each trial. Trials ended when mice climbed onto the platform, with a maximum searching time of $90 \mathrm{~s}$. Mice that did not find the platform were 
gently guided and placed on it for $20 \mathrm{~s}$. Animals were trained with two trials per day, for five consecutive days. The first trials were conducted from 10:00 a.m., mice were left undisturbed in their home cage before the second trials at 2:00 p.m. Saline or choline $(0.30 \mathrm{mg} / \mathrm{kg}$, free base, s.c.) was injected and mice were tested 15 min later. The mean latency $(\mathrm{sec})$, the mean distance traveled $(\mathrm{m})$, the swimming speed $(\mathrm{m} / \mathrm{min})$ and the number of successful trials were calculated for each mouse.

\section{STATISTICAL ANALYSIS}

Data from autoradiographic experiments were subjected to factorial oneand two-way analysis of variance (ANOVA), with genotype and area as betweengroup factors. Significant main effects were further analyzed by post hoc comparison of means using Fisher's exact test. Behavioral data were subjected to factorial two-, three- or four-way ANOVA, with genotype, sex and treatment as between-group factors and time as within-group factor. Significant main effects were further analyzed by comparison of means using Fisher's test. The numbers of successful trials in the water maze tests were compared by the Kolmogorov-Smirnov non-parametric test. 


\section{RESULTS}

\section{Quantification of the acetylcholine/nicotinic components}

Statistical analysis of the density of some cholinergic/nicotinic components showed no significant effect of genotype on ACh esterase (AChE; Fig. 1, Table 1), but a significant effect of genotype on the vesicular $A C h$ transporter (VAChT; genotype: $F_{1,64}=4.92, p<0.05$; genotype $x$ area: $F_{6,64}=2.17$, $p=0.05)$. The density of VAChT was decreased by $33 \%$ in the CA1 field of the hippocampus in STOP KO compared with WT mice ( $p<0.01)$, with no significant modification in the CA3 field nor in the entire dorsal hippocampus. The density of VAChT was not modified in the other areas tested.

In all areas tested in this study, $\left.{ }^{125} \mathrm{I}\right]$-epibatidine at low concentration is a specific ligand of $\beta 2^{\star}$ subunits (Marks et al., 2006): its autoradiographic labelling is entirely suppressed in mice lacking the $\beta 2$ subunit gene (Zoli et al., 1998) and recovered by its re-expression in the ventral tegmental area (Maskos et al., 2005). No variation in $\beta 2^{\star} n A C h R$ subunit density was found between WT and STOP KO mice (Fig. 1, Table 2). Analysis of the density of $\alpha 6^{*}$ subunits showed a significant effect of genotype (genotype: $F_{1,44}=15.87, p<0.01$; genotype $x$ area: $\left.F_{4,44}=2.85, p<0.05\right)$. The density of $\alpha 6^{*}$ subunits was significantly decreased in STOP KO mice by $19 \%$ in the striatum ( $p=0.01)$ and by $33 \%$ in the shell part of the nucleus accumbens ( $p<0.01$ ). It was not modified in the substantia nigra, the ventral tegmental area and the core part of the nucleus accumbens. Analysis of the density of $\alpha 7$ nAChRs showed a significant effect of genotype (genotype: $F_{1,78}=8.32$, $p<0.01$; genotype $x$ area: $F_{9,78}=3.02, p<0.01$ ). The density of $\alpha 7$ nAChRs in STOP KO mice was significantly increased by $24 \%$ in the dorso-lateral striatum $(p=0.05)$ and in the entire dorsal hippocampus ( $p<0.05$ ). This latter effect was accounted for by the $51 \%$ increase in the CA1 field ( $p<0.01$ ) and the $67 \%$ increase in the CA3 field ( $p<0.01$ ). Density of $\alpha 7$ $n A C h R s$ was not modified in the substantia nigra, the ventral tegmental area, the nucleus accumbens, the medial septum and the cingulate cortex.

These data suggest that the deletion of the protein STOP elicited alterations in the density of ACh markers, restricted to some proteins and to some areas.

\section{Effects of nicotine on the locomotor activity}

In order to evaluate the potential consequences of the altered VAChT and $n A C h R$ densities, we first studied the locomotor effects of nicotine (Fig. 2). Since male and female mice of each genotype did not show any significant difference in locomotor activity (not shown), their data were pooled. Statistical analysis showed a significant effect of genotype, treatment and time on the horizontal locomotor activity of mice (genotype: $F_{1,1078}=22.68$, p 0.01 ; treatment: 
$F_{6,1078}=10.17, p<0.01$; genotype $x$ treatment: $F_{6,1078}=2.34$, $p<0.05$; genotype $x$ treatment $x$ time: $F_{66,1078}=1.29, p=0.05$ ).

Nicotine at $0.5 \mathrm{mg} / \mathrm{kg}$ had no significant effect on the horizontal locomotion of WT mice, but significant increased by $130 \%$ the locomotor activity of STOP KO mice (genotype: $F_{1,132}=10.26$, p 0.01 ; Figs. $2 A, B, C$ ). At doses greater than $0.5 \mathrm{mg} / \mathrm{kg}$, nicotine elicited a dose-dependent hypolocomotor effect in both WT and STOP KO mice (genotype: $F_{1,396}=14.89$, p 0.01 ; treatment: $F_{2,396}=55.70$, $p<0.01$; genotype $x$ treatment: $F_{2,396}=5.10$, $p<0.05$ ), with a significant effect of genotype at $1.0 \mathrm{mg} / \mathrm{kg}$ (genotype: $F_{1,132}=15.77, p<0.01$ ). Analysis of the dose-effect of nicotine gave an ID $50 \%=1.6 \mathrm{mg} / \mathrm{kg}$ and a maximal inhibition (Imax) $=100 \%$ for mice of both genotypes (Fig. 2C).

Statistical analysis of the nicotine effects on the vertical activity showed a significant effect of genotype and treatment (genotype: $F_{1,1078}=8.40$, p 0.01 ; treatment: $F_{6,1078}=8.03$, p $<0.01$; Fig. 2D). Effect of nicotine at $0.1 \mathrm{mg} / \mathrm{kg}$ was significantly different in WT and STOP KO mice (genotype: $F_{1,132}=14.87$, $\mathrm{p}<0.01$ ). At doses greater than $0.5 \mathrm{mg} / \mathrm{kg}$, nicotine elicited a dose-dependent hypolocomotor effect in WT and STOP KO mice (treatment: $F_{2,396}=11.84, p<0.01$ ), with an ID50\%=1.0 mg/kg for WT mice and $1.1 \mathrm{mg} / \mathrm{kg}$ for mutant mice and an Imax $100 \%$ in both mouse lines. Finally, the absence of effect of nicotine at $0.25 \mathrm{mg} / \mathrm{kg}$ on the vertical locomotor activity of STOP KO mice demonstrated that the increased horizontal locomotion induced by nicotine at this dose was not due to an inhibition of vertical activity.

These results suggest that STOP KO mice were hypersensitive to the stimulant locomotor effect of nicotine, but not to its depressant effect.

\section{Effects of choline on the locomotor activity}

Statistical analysis showed a significant effect of genotype and choline treatment on the horizontal locomotor activity of mice (genotype: $F_{1,572}=19.65$, $p<0.01$; treatment: $F_{3,572}=2.54, p=0.06$; genotype $x$ treatment: $F_{3,572}=2.81, p<0.05$; Fig. 3). Choline $0.3 \mathrm{mg} / \mathrm{kg}$ had no significant effect on the horizontal locomotion of WT mice and STOP KO mice. At higher doses, choline had no effect on the locomotion of WT mice, but significantly increased the locomotor activity of STOP KO mice, by $116 \%$ at $3.0 \mathrm{mg} / \mathrm{kg}$ (genotype: $F_{1,143}=7.55, \mathrm{p}<0.05$ ) and by $166 \%$ at $30 \mathrm{mg} / \mathrm{kg}$ (genotype: $F_{1,154}=15.51, p<0.01$ ).

These results suggest that choline at relatively high doses had stimulant locomotor effect in mutant mice.

Effect of choline on performance of WT and STOP KO mice in the cued version of the water maze

Animals of both genotypes received saline or $0.30 \mathrm{mg} / \mathrm{kg}$ choline, $15 \mathrm{~min}$ before each trial (Fig. 4). At this time and dose, choline had no effect on the swimming 
speed of either WT or STOP KO mice (not shown). Analysis of performance of mice showed a significant effect of genotype and treatment between day 2 and day 5 on the latency (genotype: $F_{1,105}=5.03$, $p<0.05$; treatment: $F_{1,105}=11.88$, $p<0.01$; genotype $x$ treatment: $F_{1,105}=4.01, p=0.05$; genotype $x$ treatment $x$ training: $F_{3,105}=2.89, p<0.05$ ) and the distance (genotype: $F_{1,105}=9.30, p<0.01$; treatment: $F_{1,105}=15.09$, $p<0.01$; genotype $x$ treatment: $F_{1,105}=3.73, p=0.06$; genotype $x$ treatment $x$ training: $F_{3,105}=7.85$, $p<0.01$ ).

The performance of STOP KO mice were significantly lower, compared with that of WT mice. The latency time of mutant mice was longer by $27 \%$ between day 2 and day 5 (genotype: $F_{1,51}=4.59, p<0.05$ ). Mutant mice traveled more distance to reach the platform, by $14 \%$ between day 2 and day 5 (genotype $x$ training: $F_{3,51}=3.92, p<0.05$ ) and by $26 \%$ between day 3 and day 5 (genotype: $\left.F_{1,34}=5.56, p<0.05\right)$. Finally, the proportion of successful trials of STOP KO mice was significantly lower than WT mice (Chi2=3.20, p<0.05).

Choline treatment had no effect on the latency and distance traveled by WT mice, but significantly increased their proportion of successful trials (Chi2 $=4.35, \mathrm{p}<0.05$ ). In contrast, choline treatment improved the performance of STOP KO mice, assessed by the three parameters. Compared with salinetreatment between days 2 and 5 , choline decreased the latency time by $27 \%$ (treatment: $F_{1,51}=8.51, p<0.01$ ) and the distance swum by $17 \%$ (treatment: $\left.F_{1,51}=15.51, p<0.01\right)$ and increased the proportion of successful trials of STOP KO mice (Chi2 $=3.76, p<0.05$ ). Finally, performance of choline-treated STOP KO mice and saline-treated WT mice were no longer different (genotype: latency $F_{1,48}=1.55$, distance $F_{1,48}=0.21$, number of successful trials $C h i 2=0.20$ ).

Our data show that choline at low doses improved the impaired performance of STOP KO mice in the cued Morris test to a higher extent than WT mice. 


\section{DISCUSSION}

The constitutive inactivation of the ubiquitous protein STOP elicited modified VAChT and nicotinic receptor densities, in an area- and sub-type dependent-manner. The altered densities of ACh markers have functional consequences, since STOP KO mice were hypersensitive to nicotine- or cholineinduced locomotor hyperactivity. Interestingly, the impaired performance of mutant mice in the cued version of the Morris water maze were greatly improved by choline at low dose, to a higher extent than WT mice.

In STOP KO mice, while the density of the ACh inactivating enzyme AChE was not modified in any brain areas, the density of the vesicular $A C h$ transporter VAChT was selectively decreased in the granular layer of the hippocampal CA1 field, but not in the CA3 field and in the median septum containing the somas of these cholinergic neurons. These results suggest that modulation of VAChT expression depends on a specific regional/neuronal environment. Importantly, a two-fold decrease in glutamatergic synaptic vesicles and in alterations of the long term potentiation and depression have been found in CA1 field of mutant mice, but not in CA3 field, also suggesting area-specific modifications (Andrieux et al., 2002). The decreased density of VAChT could result from a decreased number of cholinergic terminals and/or vesicular transporters per vesicle and/or vesicles per terminal. In any event, reduction in VAChT density might result in decreased ACh release. Interestingly, modified VAChT density was found in terminals of septo-hippocampal cholinergic neurons thought to be involved in learning and memory (Leanza et al., 1995).

The density of $\beta 2^{\star} n A C h R s$ was not modified in any area tested. In contrast, $\alpha 6$ nAChR subunit density was largely decreased in the striatum and the shell part of the nucleus accumbens and $\alpha 7$ nAChR density was greatly increased in the dorso-lateral striatum and in some layers of the dorsal hippocampus, but not in the median septum. Such opposite effects on $\alpha 6^{*}$ and $\alpha 7$ $n A C h R$ density were also found in DA transporter (DAT) KO mice, a constitutively hyperdopaminergic mouse line pertinent to schizophrenia (Giros et al., 1996; Gainetdinov et al., 2001; Weiss et al., 2007b). Altogether our results, as well as previous data (Andrieux et al., 2002; Brun et al., 2005), indicate that the deletion of the ubiquitously expressed protein STOP elicits selective alterations in various neurotransmitter systems. Indeed, these alterations depend on both proteins and brain areas. Further studies should be necessary to know if these restricted alterations are related to differential functions of STOP protein and/or other STOP-like proteins during mouse cerebral ontogenesis. 
In order to evaluate the potential consequences of the modified expression of cholinergic/nicotinic markers, we characterized two behaviors involving nicotinic neurotransmission. We chose nicotine-induced locomotor activity in relation with nicotinic alterations in the striatum and the nucleus accumbens and learning performance in the Morris water maze in relation with nicotinic alterations in the hippocampus and the striatum.

Mutant mice were hypersensitive to the stimulating locomotor effect of nicotine, in agreement with previous results with amphetamine in STOP KO mice (Brun et al., 2005) and with nicotine in DAT KO mice (Weiss et al., 2007a,b). In rodents, nicotine can increase locomotion in a familiar environment probably via activation of DAergic pathways through distinct nAChRs (Menzaghi et al., 1997; Picciotto et al., 2001). In our case, habituation of STOP KO mice to actimeter cages was not different from their WT counterparts (compare the time course of basal activities after saline administration, Fig. $1 A$ and $B$ ). The hypersensitivity of STOP KO mice to the stimulating locomotor effect of nicotine could be due to an enhanced $D A$ release effect, since nicotine induces DA release in the nucleus accumbens, as all drugs of abuse (Pontieri et al., 1996). The pertinence of this hypothesis is reinforced by recent studies showing that the DA efflux evoked by electrical stimulation is highly increased in the nucleus accumbens of STOP KO mice (Brun et al., 2005). Studies of various nAChR subunit $K O$ mice indicate that nicotine exerts its $D A$ releasing effect mainly via $\beta 2^{\star}$ nAChRs (Picciotto et al., 1998; Maskos et al., 2005). The density of nicotinic $\beta 2$ subunits was not modified in STOP KO mice but their sensitization state was not determined. Increased striatal $\alpha 7 \mathrm{nAChRs}$, if they were functional, could also participate in nicotine-induced $D A$ release, taking into account the localization of $\alpha 7$ nAChRs on glutamatergic terminals in DAergic areas (Kaiser and Wonnacott, 2000). Finally, other non-cholinergic receptors could mediate the hypersensitivity of STOP KO mice to the stimulating effect of nicotine.

Numerous studies in humans and rodents demonstrate the pro-cognitive effect of nicotine, via $\alpha 7$ nAChR stimulation (Adler et al., 1998; Levin, 2002; Levin et al., 2002; Young et al., 2004; Buccafusco et al., 2005). The highly increased $\alpha 7$ nAChR density in the hippocampus and the dorso-lateral striatum of STOP KO mice prompted us to test the cognitive performance of mice in the Morris water maze. Since the higher increase in density of $\alpha 7 \mathrm{nAChRs}$ was found in the hippocampus of STOP KO mice, we first assessed spatial learning. In this paradigm, WT mice did not learn to find the hidden platform even after eight days of training (not shown). The poor performance could result from the genetic background of the mice (50:50 BALBC/129SvPas), since both parental strains are poor performers (van Dam et al., 2006). Accordingly, we employed the cued platform version of the water maze (place task), in which mice were 
trained to swim to a platform mounted with a visible cue and placed in a different location on each trial. Such learning is thought to be mediated by the basal ganglia, in particular the dorsal striatum (Packard and Knowlton, 2002), where $\alpha 7$ nAChR density was also increased in STOP KO mice. In cued version, STOP KO mice showed impaired performance compared with WT littermates. Contrary to WT mice whose performance improved during the successive trials, mutant mice did not learn to find the platform during the five-day training period. Consequently, we tested the effect of choline, a preferential $\alpha 7 \mathrm{nAChR}$ agonist at low doses (Papke et al., 1996; Matsuyama and Matsumoto, 2003). We first assessed its effect on locomotor activity. Whereas choline had no effect on the locomotion of WT mice, it increased the activity of STOP KO mice. However, this effect was elicited by choline at relatively high doses, for which it can serve as substrate for $A C h$ synthesis and can stimulate non- $\alpha 7$ nicotinic and muscarinic AChRs. Thus, we chose the lowest ineffective dose of choline $(0.3 \mathrm{mg} / \mathrm{kg})$ to test its potential effect on learning in WT and STOP KO mice. At this dose, choline had no effect on the swimming speed of mice.

Administered 15 minutes before trials, choline improved performance of both WT and STOP KO mice, but to a higher extent in mutant mice. Indeed, choline increased the proportion of successful trials of WT mice, but had no effect on their latency and distance traveled. In contrast, choline significantly decreased the latency and distance swam by STOP KO mice and increased their number of successful trials. Altogether, the performance of choline-treated STOP KO mice were no longer different from saline-treated WT mice. The procognitive effect of choline is thought to be a central one, since choline did not affect the swimming speed of WT and STOP KO mice and since its effect was rather selective for mutant mice. The preferential pro-cognitive effect of choline in STOP KO mice can be related to the pro-cognitive effect of nicotine in DAT KO mice, both in the spatial and cued versions of the Morris water maze (Weiss et al., 2007a).

A recent study demonstrates that stimulation of both $\alpha 4 \beta 2$ and $\alpha 7$ nAChRs, by epibatidine and choline respectively, are essential for fulldevelopment of long-term potentiation in the mouse dentate gyrus (Matsuyama and Matsumoto, 2003). Reports also indicate that working memory in rats is improved by stimulation or co-stimulation of $\alpha 4 \beta 2$ and $\alpha 7$ nAChRs in the hippocampus and/or amygdala (Levin, 2002; Levin et al., 2002). Various studies also implicate cholinergic neurotransmission in the dorsal striatum in learning tasks that associate a stimulus with a response (Packard and Knowlton, 2002). The failure of STOP KO mice to learn the cued version of the water maze can hardly be explained by the increased $\alpha 7 n A C h R$ density in the dorso-lateral striatum. This suggests that the up-regulated $\alpha 7 \mathrm{nAChRs}$ are non-functional, being desensitized or under-stimulated. The latter hypothesis seems more likely: 
first, in hippocampus, another area implicated in cognitive behavior, up-regulated $\alpha 7$ nAChRs were associated with decreased density of VAChT, suggesting reduced $A C h$ release in that region. Second, choline improved the impaired performance of STOP KO mice. The pro-cognitive effect of choline at low dose on STOP KO mice, probably via $\alpha 7$ nAChR stimulation, was reinforced by recent data of our lab showing that impaired performance of DAT KO mice in the cued version of the water maze was improved by $D M X B-A$, another $\alpha 7$ nAChR agonist (El Khoury et al., in preparation). Another non-exclusive hypothesis to explain the impaired performance of STOP KO mice would be an imbalance between $\beta 2^{*}$ (not modified) and $\alpha 7$ (increased) $n A C h R$ densities in some brain areas, in agreement with previous reports (Levin et al., 2002).

Finally, the beneficial effect of choline on performance of WT mice and its higher effect in STOP KO mice can be due to a hypersensitive response of mutant mice to the pro-cognitive effect of choline. They are also reminiscent of studies on cognitive performance in humans. Although the pro-cognitive effect of nicotine in healthy humans is debated, there is clearer evidence for nicotinic modulation of cognitive dysfunction in several neuropsychiatric disorders, including Alzheimer's and Parkinson's diseases, ADHD and schizophrenia (Sacco et al., 2004).

In conclusion, our present study shows that the deletion of the microtubule-regulating protein STOP can induce significant adaptation of the cholinergic/nicotinic neurotransmission. Paradoxically, the lack of STOP, an ubiquitously expressed protein, induced alterations of cholinergic/nicotinic transmission in a protein- and area-dependent manner. Altogether, our data suggest that nicotinic neurotransmission is probably deficient in STOP mutant mice and that these mice may represent a useful experimental model for studying cognitive deficits and testing the potential benefits of therapeutic treatments by nicotine or nicotinic agonists.

Acknowledgements: The authors thank Drs M. Nosten-Bertrand and C. Betancur (Inserm U513) for helpful discussion and D. Proietto (Inserm U366) for mouse genotyping. This work was supported by Inserm ( $A A, A S, D J, B G, M P M)$ and by NIH MH 53631 and DA12242 (JMM). CBV and SW were the recipients of a fellowship from MILDT and the "Société de Tabacologie", respectively. 


\section{REFERENCES}

Adler, L. E., Olincy, A., Waldo, M., Harris, J.G., Griffith, J., Stevens, K., Flach, K., Nagamoto, H., Bickford, P., Leonard, S., Freedman, R., 1998. Schizophrenia, sensory gating, and nicotinic receptors. Schizophrenia Bull 24, 189-202.

Andrieux, A., Salin, P. A., Vernet, M., Kujala, P., Baratier, J., Gory-Faure, S., Bosc, C., Pointu, H., Proietto, D., Schweitzer, A., Denarier, E., Klumperman, J., Job, D., 2002. The suppression of brain cold-stable microtubules in mice induces synaptic defects associated with neuroleptic-sensitive behavioral disorders. Genes Dev $16,2350-2364$.

Bosc, C., Cronk, J.D., Pirollet, F., Watterson, D.M., Haiech, J., Job, D., Margolis, R.L. (1996) Cloning, expression, and properties of the microtubule-stabilizing protein STOP. Proc. Natl. Acad. Sci. USA 93, 2125-2130.

Breese, C. R., Lee, M. J., Adams, C. E., Sullivan ,B., Logel, J., Gillen, K. M., Marks, M. J., Collins, A. C., Leonard, S., 2000. Abnormal regulation of high affinity nicotinic receptors in subjects with schizophrenia. Neuropsychopharmacology 23, 351364.

Brun, P., Begou, M., Andrieux, A., Mouly-Badina, L., Clerget, M., Schweitzer, A., Scarna, H., Renaud, B., Job, D., Suaud-Chagny, M. F., 2005. Dopaminergic transmission in STOP null mice. J.Neurochem. 94, 63-73.

Buccafusco, J. J., Letchworth, S. R., Bencheri,f M., Lippiello, P. M., 2005. Long-lasting cognitive improvement with nicotinic receptor agonists: mechanisms of pharmacokinetic-pharmacodynamic discordance. Trends Pharmacol 26, 352-360.

de Leon, J., Dadvand, M., Canuso, C., White, A. O., Stanilla, J. K., Simpson, G. M., 1995. Schizophrenia and smoking: an epidemiological survey in a state hospital. Am. J. Psychiatry 152, 453-455.

Eastwood, S.L., Lyon, L., George, L., Andrieux, A., Job, D., Harrison, P.J., 2006. Altered expression of synaptic protein mRNAs in STOP (MAP-6) mutant mice. J. Psychopharmacol, in press.

Fradley, R. L., O'Meara ,G. F., Newman, R. J., Andrieux, A., Job, D., Reynolds, D. S., 2005. STOP knockout and NMDA NR1 hypomorphic mice exhibit deficits in sensorimotor gating. Behav Brain Res 163, 257-264. 
Frankle, W. G., Lerma, J., Laruelle, M., 2003. The synaptic hypothesis of schizophrenia. Neuron 39, 205-216.

Freedman, R., Hall, M., Adler, L. E., Leonard, S., 1995. Evidence in postmortem brain tissue for decreased numbers of hippocampal nicotinic receptors in schizophrenia. Biol. Psychiatry 38, 22-33.

Freedman, R., Coon, H., Myles-Worsley, M., Orr-Urtreger, A., Olincy, A., Davis, A., Polymeropoulos, M., Holik, J., Hopkins, J., Hoff, M., Rosenthal, J., Waldo, M.C., Reimherr, F., Wender, P., Yaw, J., Young, D.A., Breese, C.R., Adams, C., Patterson, D., Adler, L.E., Kruglyak, L., Leonard, S., Byerley, W., 1997. Linkage of a neurophysiological deficit in schizophrenia to a chromosome 15 locus. Proc. Natl. Acad. Sci. U S A 94, 587-592.

Gainetdinov, R. R., Mohn, A. R., Caron, M. G., 2001. Genetic animal models: focus on schizophrenia. Trends Neurosci. 24, 527-533.

Giros, B., Jaber, M., Jones, S. R., Wightman, R. M., Caron, M. G., 1996. Hyperlocomotion and indifference to cocaine and amphetamine in mice lacking the dopamine transporter. Nature 379, 606-612.

Glassman, A. H. 1993. Cigarette smoking: implications for psychiatric illness. Am. J. Psychiatry 150, 546-553.

Guillaud L., Bosc C., Fourest-Lieuvin A., Denarier E., Pirollet F., Lafanechere L. and Job D. (1998) STOP proteins are responsible for the high degree of microtubule stabilization observed in neuronal cells. J. Cell Biol. 142, 167-179.

Kaiser, S., Wonnacott, S., 2000. Alpha-bungarotoxin-sensitive nicotinic receptors indirectly modulate $[(3) \mathrm{H}]$ dopamine release in rat striatal slices via glutamate release. Mol. Pharmacol. 58, 312-318.

Kumari, V., Postma, P., 2005. Nicotine use in schizophrenia: the self medication hypotheses. Neurosci. Biobehav. Rev. 29, 1021-1034.

Leanza, G., Nilsson, O.G., Wiley, R.G., Bjorklund, A., 1995. Selective lesioning of the basal forebrain cholinergic system by intraventricular 192 IgG-saporin: behavioral, biochemical and stereological studies in the rat. Eur. J. Neurosci. 7 , 329-343. 
Leonard, S., Gault, J., Hopkins, J., Logel, J., Vianzon, R., Short, M., Drebing, C., Berger, R., Venn, D., Sirota, P., Zerbe, G., Olincy, A., Ross, R.G., Adler, L.E., Freedman, R., 2002. Association of promoter variants in the alpha7 nicotinic acetylcholine receptor subunit gene with an inhibitory deficit found in schizophrenia. Arch. Gen. Psychiatry 59, 1085-1096.

Levin, E. D., 2002. Nicotinic receptor subtypes and cognitive function. J. Neurobiol. $53,633-640$.

Levin, E. D., Bradley, A., Addy, N., Sigurani, N., 2002. Hippocampal alpha 7 and alpha 4 beta 2 nicotinic receptors and working memory. Neuroscience 109, 757-765.

Marks, M.J., Whiteaker, P., Collins, A.C., 2006. Deletion of the \{alpha\}7, \{beta\}2 or \{beta\}4 Nicotinic Receptor Subunit Genes Identifies Diverse, Highly Expressed Binding Sites with Relatively Low Affinity for [3H]Epibatidine. Mol. Pharmacol. 70, 947-959.

Marsh, D., Grassi, J., Vigny, M., Massoulie, J., 1984. An immunological study of rat acetylcholinesterase: comparison with acetylcholinesterases from other vertebrates. J. Neurochem. 43, 204-213.

Maskos, U., Molles, B. E., Pons, S., Besson, M., Guiard, B.P., Guilloux, J.P., Evrard, A., Cazala, P., Cormier, A., Mameli-Engvall, M., Dufour, N., Cloez-Tayarani, I., Bemelmans, A.P., Mallet, J., Gardier, A.M., David, V., Faure, P., Granon, S., Changeux, J.P., 2005. Nicotine reinforcement and cognition restored by targeted expression of nicotinic receptors. Nature 436, 103-107.

Matsuyama, S., and Matsumoto A., 2003. Epibatidine induces long-term potentiation (LTP) via activation of alpha4beta2 nicotinic acetylcholine receptors ( $N A C h R s$ ) in vivo in the intact mouse dentate gyrus: both alpha7 and alpha4beta2 nAChRs essential to nicotinic LTP. J. Pharmacol. Sci. 93, 180-187.

Menzaghi, F., Whelan, K. T., Risbrough, V. B., Rao, T. S., Lloyd, G. K., 1997. Effects of a novel cholinergic ion channel agonist SIB-1765F on locomotor activity in rats. J. Pharmacol. Exp. Ther. 280, 384-392.

Mihailescu, S., Drucker-Colin, R., 2000. Nicotine, brain nicotinic receptors, and neuropsychiatric disorders. Arch. Med. Res. 31, 131-144. 
Mirnics, K., Middleton, F. A., Lewis, D. A., Levitt, P., 2001. Analysis of complex brain disorders with gene expression microarrays: schizophrenia as a disease of the synapse. Trends Neurosci. 24, 479-486.

Packard, M. G., Knowlton, B. J., 2002. Learning and memory functions of the Basal Ganglia. Ann. Rev. Neurosci. 25, 563-593.

Papke, R.L., Bencherif, M., Lippiello, P., 1996. An evaluation of neuronal nicotinic acetylcholine receptor activation by quaternary nitrogen compounds indicates that choline is selective for the alpha 7 subtype. Neurosci. Lett. 213, 201-204.

Perry, D.C., Kellar, K.J., 1995. [3H] ]epibatidine labels nicotinic receptors in rat brain: an autoradiographic study. J. Pharmacol. Exp. Ther. 275, 1030-1034.

Picciotto, M. R., Caldarone, B. J., Brunzell, D. H., Zachariou, V., Stevens, T. R., King ,S. L., 2001. Neuronal nicotinic acetylcholine receptor subunit knockout mice: physiological and behavioral phenotypes and possible clinical implications. Pharmacol. Ther. 92, 89-108.

Picciotto, M. R., Zoli, M., Rimondini, R., Lena, C., Marubio, L. M., Pich, E. M., Fuxe, K., Changeux, J.-P., 1998. Acetylcholine receptors containing the [beta]2 subunit are involved in the reinforcing properties of nicotine. Nature 391, 173-177.

Pontieri, F.E., Tanda, G., Orzi, F., Di Chiara, G., 1996. Effects of nicotine on the nucleus accumbens and similarity to those of addictive drugs. Nature 382, 255257.

Sacco, K.A., Bannon, K.L., George, T.P., 2004. Nicotinic receptor mechanisms and cognition in normal states and neuropsychiatric disorders. J. Psychopharmacol. $18,457-474$.

Shimizu, H., Iwayama, Y., Yamada, K., Toyota, T., Minabe, Y., Nakamura, K., Nakajima, M., Hattori, E., Mori, N., Osumi, N., Yoshikawa, T., 2006. Genetic and expression analyses of the STOP (MAP6) gene in schizophrenia. Schizophrenia Res. 84, 244252.

Spurden, D. P., Court, J. A., Lloyd, S., Oakley, A., Perry, R., Pearson, C., Pullen, R. G., Perry, E. K., 1997. Nicotinic receptor distribution in the human thalamus: autoradiographical localization of [3H]nicotine and [125I] alpha-bungarotoxin binding. J. Chem. Neuroanat. 13, 105-113. 
van Dam, D., Lenders, G., De Deyn, P.P., 2006. Effect of Morris water maze diameter on visual-spatial learning in different mouse strains. Neurobiol. Learn. Mem. 85,164-172.

van Rossum, D., Hanisch, U. K., 1999. Cytoskeletal dynamics in dendritic spines: direct modulation by glutamate receptors? Trends Neurosci. 22, 290-295.

Weiss, S., Nosten-Bertrand, M., McIntosh, J.M., Giros, B., Martres, M-P., 2007a. Nicotine improves cognitive deficits of dopamine transporter knock-out mice without long-term tolerance. Neuropsychopharmacology, doi: 10.1038/ sj.npp.13011385.

Weiss, S., Tzavara, E.T., Davis, R.J., Nomikos, G.G., McIntosh, J.M., Giros, B., Martres, M-P., 2007b. Functional alterations of nicotinic neurotransmission in dopamine transporter knock-out mice. Neuropharmacol., doi:10.1016/ j.neuropharm.2007.02.002.

Whiteaker, P., McIntosh, J. M., Luo, S., Collins, A. C., Marks, M. J., 2000. 125I-alphaconotoxin MII identifies a novel nicotinic acetylcholine receptor population in mouse brain. Mol. Pharmacol. 57, 913-925.

Young, J. W., Finlayson, K., Spratt, C., Marston, H. M., Crawford, N., Kelly, J. S., Sharkey, J., 2004. Nicotine improves sustained attention in mice : evidence for involvement of the alpha7 nicotinic acetylcholine receptor. Neuropsychopharmacology 29, 891-900.

Zoli, M., Lena, C., Picciotto, M. R., Changeux, J. P., 1998. Identification of four classes of brain nicotinic receptors using beta2 mutant mice. J. Neurosci. 18, 44614472. 
Table 1 Density of cholinergic markers in WT and STOP KO mice

\begin{tabular}{|c|c|c|c|c|}
\hline Marker & Area & WT & KO & $\%$ KO/WT \\
\hline \multirow[t]{9}{*}{ AChE } & SNC & (4) $235 \pm 7$ & (4) $263 \pm 14$ & $+12 \%$ ns \\
\hline & SNR & (5) $167 \pm 9$ & (5) $177 \pm 10$ & $+6 \% n s$ \\
\hline & VTA & (3) $269 \pm 13$ & (6) $290 \pm 11$ & $+8 \% n s$ \\
\hline & Striatum & (6) $335 \pm 12$ & (5) $331 \pm 12$ & $-1 \%$ ns \\
\hline & Acc Shell & (4) $352 \pm 23$ & (4) $356 \pm 16$ & $+1 \%$ ns \\
\hline & Acc Core & (3) $295 \pm 15$ & (4) $294 \pm 22$ & $0 \%$ \\
\hline & Dorsal Hipp & (6) $57 \pm 1$ & (5) $60 \pm 3$ & $+5 \%$ ns \\
\hline & CA1 & (5) $90 \pm 3$ & (5) $88 \pm 4$ & $-2 \% n s$ \\
\hline & $C A 3$ & (6) $71 \pm 4$ & (6) $73 \pm 5$ & $+3 \% n s$ \\
\hline \multirow[t]{9}{*}{ VAChT } & SN & ND & ND & \\
\hline & VTA & ND & ND & \\
\hline & Striatum & (6) $182 \pm 10$ & (6) $181 \pm 7$ & $-1 \% n s$ \\
\hline & Acc Shell & (6) $224 \pm 18$ & (6) $233 \pm 20$ & $+4 \% n s$ \\
\hline & Acc Core & (6) $156 \pm 9$ & (6) $166 \pm 8$ & $+6 \% n s$ \\
\hline & Dorsal Hipp & (5) $39.5 \pm 1.6$ & (5) $32.8 \pm 1.6$ & $-17 \%$ ns \\
\hline & CA1 & (5) $30.6 \pm 1.3$ & (5) $20.6 \pm 1.4$ & 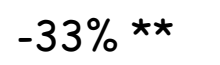 \\
\hline & $\mathrm{CA} 3$ & (5) $46.8 \pm 2.9$ & (5) $48.7 \pm 5.1$ & $+4 \% n s$ \\
\hline & Septum & (6) $180 \pm 13$ & (6) $154 \pm 15$ & $-14 \%$ ns \\
\hline
\end{tabular}

Densities are the means \pm SEM of immunolabeling in $\mathrm{nCi} / \mathrm{mg}$. The number of mice is indicated in parentheses. ND, not detectable; $A c c$, nucleus accumbens; AChE, acetylcholine esterase; CA1, CA3, CA1 and CA3 fields of hippocampus; Dorsal Hipp, dorsal hippocampus; SN, substantia nigra; SNC, substantia nigra, pars compacta; SNR substantia nigra, pars reticulata; VAChT, vesicular acetylcholine transporter; VTA, ventral tegmental area.

Fisher's test: ${ }^{\star \star} p<0.01$. 
Table 2 Density of nicotinic receptors in WT and STOP KO mice

\begin{tabular}{|c|c|c|c|c|}
\hline Receptor & Area & WT & KO & $\% \mathrm{KO} / \mathrm{WT}$ \\
\hline \multirow[t]{7}{*}{$\beta 2^{\star}$} & SN & (5) $126 \pm 5$ & (4) $119 \pm 11$ & $-6 \% n s$ \\
\hline & VTA & (5) $333 \pm 16$ & (4) $313 \pm 13$ & $-6 \% n s$ \\
\hline & Striatum & (6) $242 \pm 12$ & (6) $215 \pm 18$ & $-11 \% n s$ \\
\hline & Acc Shell & (6) $193 \pm 11$ & (6) $211 \pm 2$ & $+9 \%$ ns \\
\hline & Acc Core & (5) $166 \pm 9$ & (5) $180 \pm 11$ & $+8 \% n s$ \\
\hline & Dorsal Hipp & (6) $133 \pm 10$ & (6) $126 \pm 6$ & $-5 \% n s$ \\
\hline & Cing $C x$ & (5) $225 \pm 5$ & (4) $216 \pm 10$ & $-4 \% n s$ \\
\hline \multirow[t]{5}{*}{$\alpha 6^{*}$} & SNC & (5) $155 \pm 9$ & (4) $156 \pm 9$ & $0 \%$ \\
\hline & VTA & (4) $225 \pm 27$ & (5) $210 \pm 21$ & $-7 \% n s$ \\
\hline & Striatum & (6) $179 \pm 6$ & (6) $145 \pm 4$ & 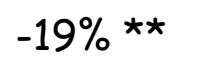 \\
\hline & Acc Shell & (6) $225 \pm 7$ & (6) $151 \pm 8$ & 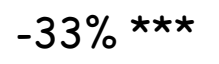 \\
\hline & Acc Core & (6) $192 \pm 5$ & (6) $173 \pm 10$ & $-10 \%$ ns \\
\hline \multirow[t]{10}{*}{$\alpha 7$} & SN & (5) $50.0 \pm 4.9$ & (5) $48.0 \pm 8.3$ & $-4 \% n s$ \\
\hline & VTA & (6) $143 \pm 11$ & (4) $132 \pm 20$ & $-8 \% n s$ \\
\hline & Str DL & (5) $65.0 \pm 4.7$ & (4) $80.4 \pm 2.4$ & $+24 \%$ * \\
\hline & Acc Shell & (5) $15.3 \pm 1.4$ & (5) $14.1 \pm 2.4$ & $-8 \% n s$ \\
\hline & Acc Core & (4) $16.1 \pm 1.4$ & (4) $17.0 \pm 2.3$ & $+6 \%$ ns \\
\hline & Dorsal Hipp & (6) $74.2 \pm 3.3$ & (5) $92.2 \pm 10.3$ & $+24 \%$ * \\
\hline & CA1 & (6) $44.1 \pm 4.2$ & (4) $66.8 \pm 4.2$ & 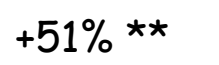 \\
\hline & $C A 3$ & (6) $58.3 \pm 3.6$ & (5) $97.5 \pm 14.8$ & 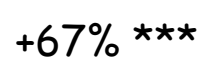 \\
\hline & Septum & (5) $40.1 \pm 3.7$ & (5) $38.6 \pm 2.6$ & $-4 \% n s$ \\
\hline & Cing $C x$ & (5) $35.2 \pm 2.4$ & (4) $32.5 \pm 2.8$ & $-8 \% n s$ \\
\hline
\end{tabular}

Densities are the means \pm SEM of specific radioligand binding in $\mathrm{nCi} / \mathrm{mg}$. The number of mice is indicated in parentheses. Acc, nucleus accumbens; CA1, CA3, CA1 and CA3 fields of hippocampus; Cing CX, cingulate cortex; Dorsal Hipp, dorsal hippocampus; SN, substantia nigra; SNC, substantia nigra, pars compacta; Str DL, dorso-lateral striatum; VTA, ventral tegmental area.

Fisher's test: ${ }^{\star} p<0.05 ;{ }^{\star \star} p<0.01 ;{ }^{\star \star \star} p<0.001$. 


\section{LEGENDS TO FIGURES}

Fig. 1: Autoradiographic representation of acetylcholine esterase (AChE), vesicular acetylcholine transporter (VAChT), $\beta 2^{*}, \alpha 6^{*}$ and $\alpha 7$ nicotinic receptors in WT and STOP KO mice.

Fig. 2: Hypersensitivity of STOP KO mice to the stimulant locomotor effect of nicotine.

Time course of the horizontal activity of WT (A) and STOP KO (B) mice after s.C. administration of saline (Sal) or nicotine (Nic) at increasing doses. Means \pm SEM of photocell counts over a 5 min period. Dose-response effects of nicotine administration on the horizontal $(C)$ and vertical $(D)$ locomotor activities of WT and STOP KO mice. Data represent means \pm SEM of photocell counts over a $60 \mathrm{~min}$ period, expressed as percentages of respective basal activities (65.5 \pm 9.0 and $63.3 \pm 7.0$ counts $/ 60$ min for horizontal activity of WT and STOP KO, respectively; $299 \pm 60$ and $246 \pm 55$ counts $/ 60 \mathrm{~min}$ for vertical activity of WT and STOP KO mice, respectively). Number of mice in parentheses: Sal (15 WT, $13 \mathrm{KO}$ ), Nic (7 WT or KO per dose).

Fisher's test: ** p 0.01 , comparison between genotypes.

Fig. 3: Stimulant locomotor effect of choline in STOP KO mice.

A: time course of the horizontal activity of WT and STOP KO mice after s.c. choline administration at various doses. Means \pm SEM of photocell counts over a 5 min period for 7-8 mice per dose. B: dose-response effects of choline administration on the horizontal locomotor activity of WT and STOP KO mice. Data represent means \pm SEM of photocell counts over a 60 min period, expressed as percentages of respective basal activity (61.6 \pm 6.0 and $35.7 \pm 8.0$ counts/60 min for horizontal activity of WT and STOP KO, respectively; $101 \pm 36$ and $151 \pm 51$ counts $/ 60 \mathrm{~min}$ for vertical activity of WT and STOP KO mice, respectively).

Fisher's test: $* *$ p $<0.01$, comparison between genotypes.

Fig. 4: Choline improved the performance of STOP KO mice in the cued version of water maze.

$15 \mathrm{Min}$ before each trial, mice received s.c. administration of saline (Sal) or choline $0.3 \mathrm{mg} / \mathrm{kg}$ (Chol). Performance of mice are expressed as latency (seconds, $s$ ) and mean distance traveled (meters, $m$ ) and proportion of successful trials. Values are means \pm SEM for 9 (WT Sal), 10 (KO Sal and KO Chol) and 11 (WT Chol) mice. 


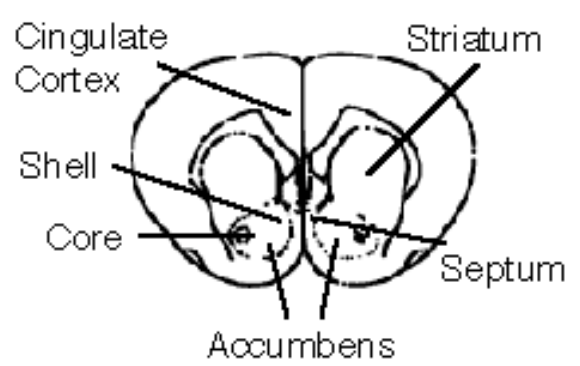

WT

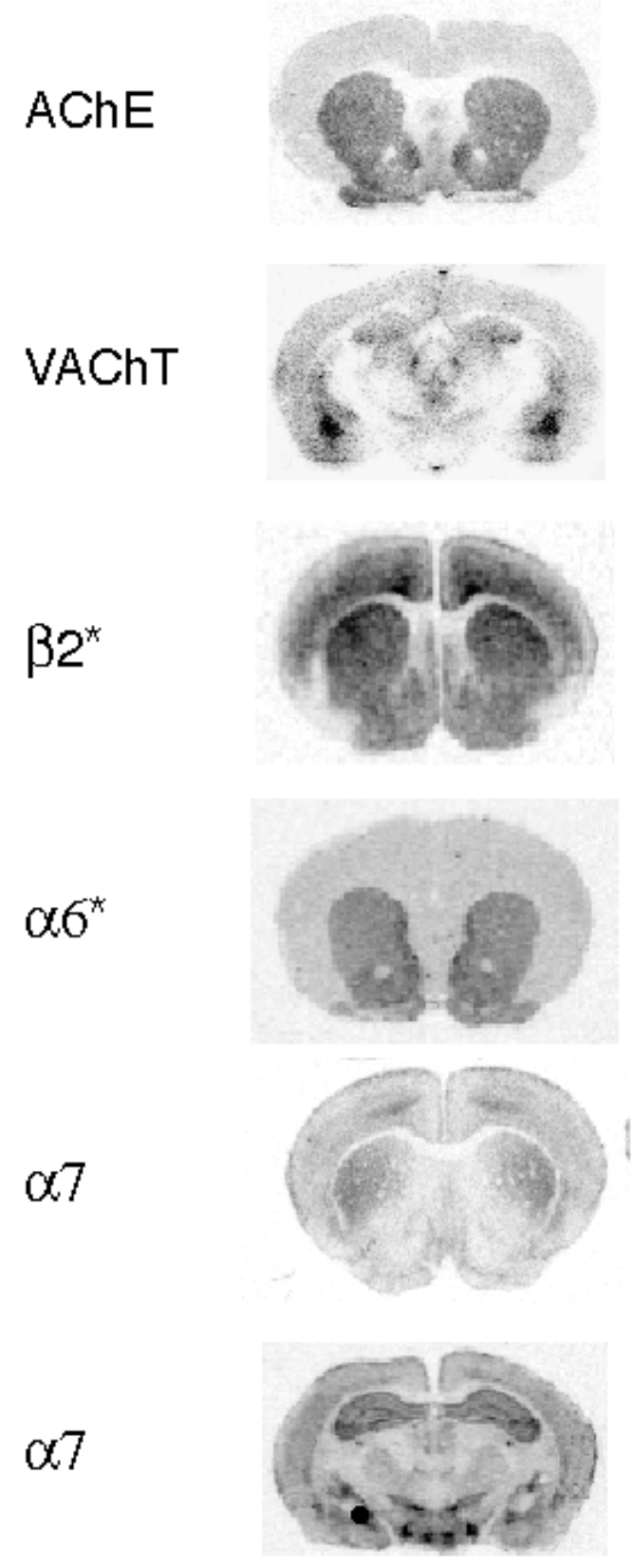

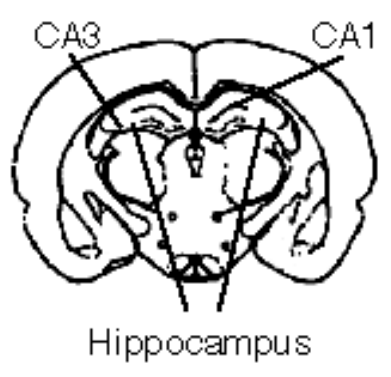

KO
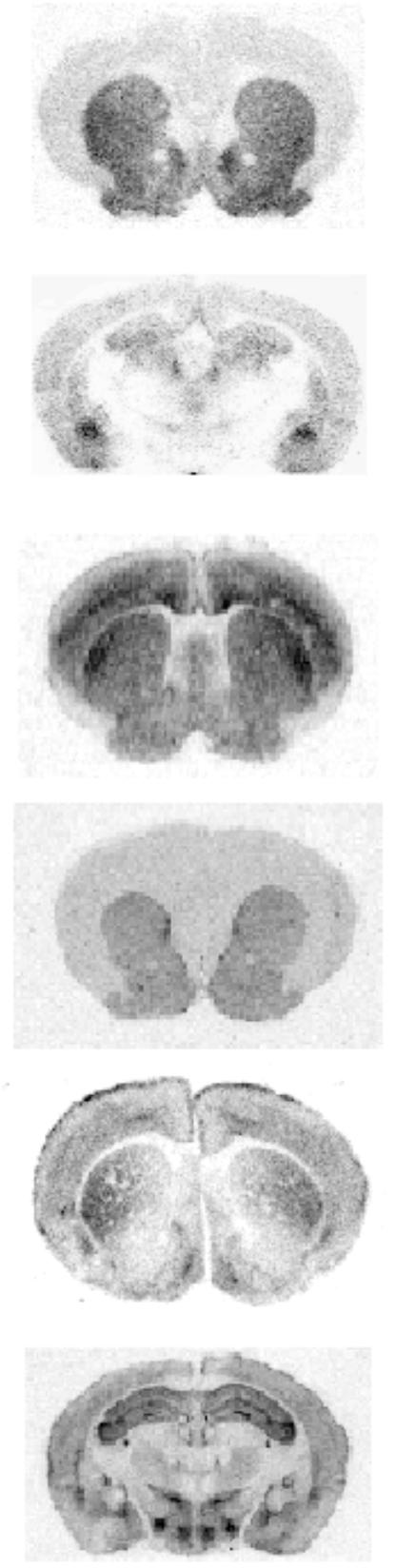

Figure 1 
A Horizontal locomotor activity

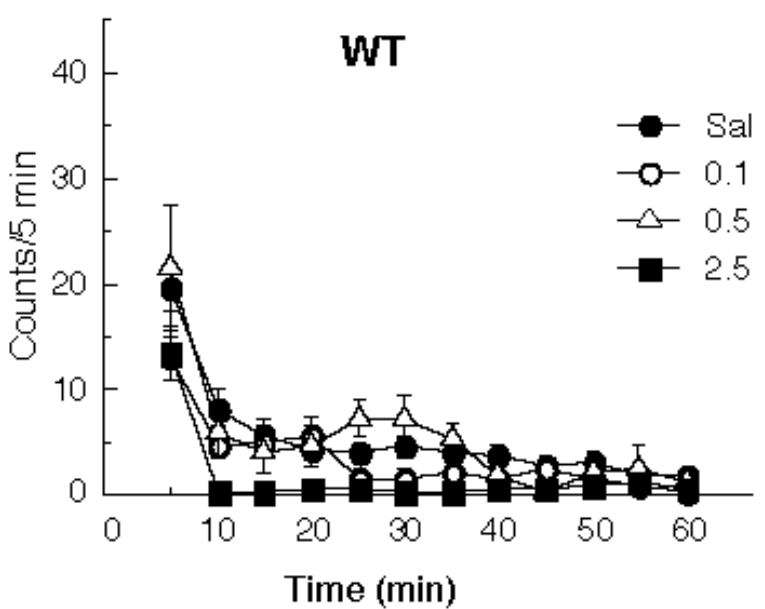

C Horizontal locomotor activity

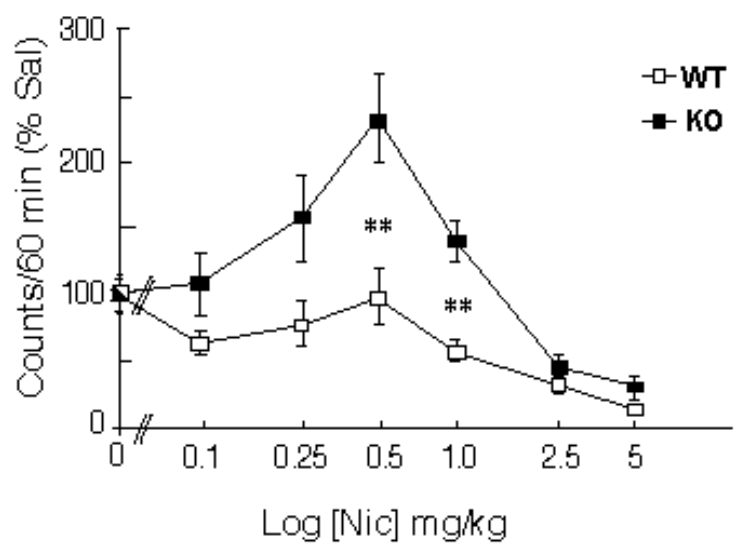

B Horizontal locomotor activity

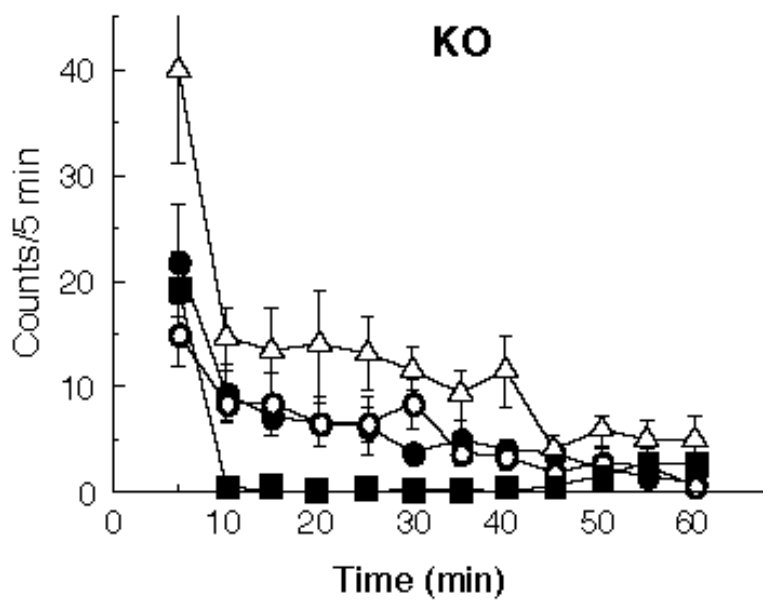

D Vertical locomotor activity

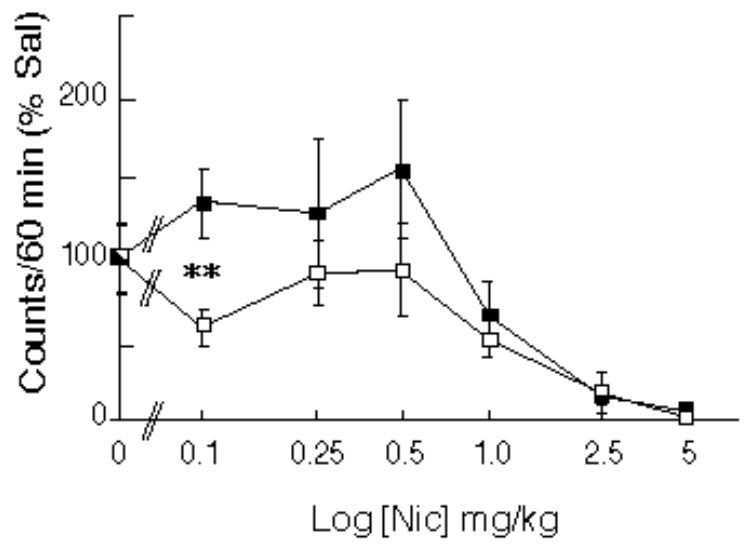

Figure 2 
A Time course
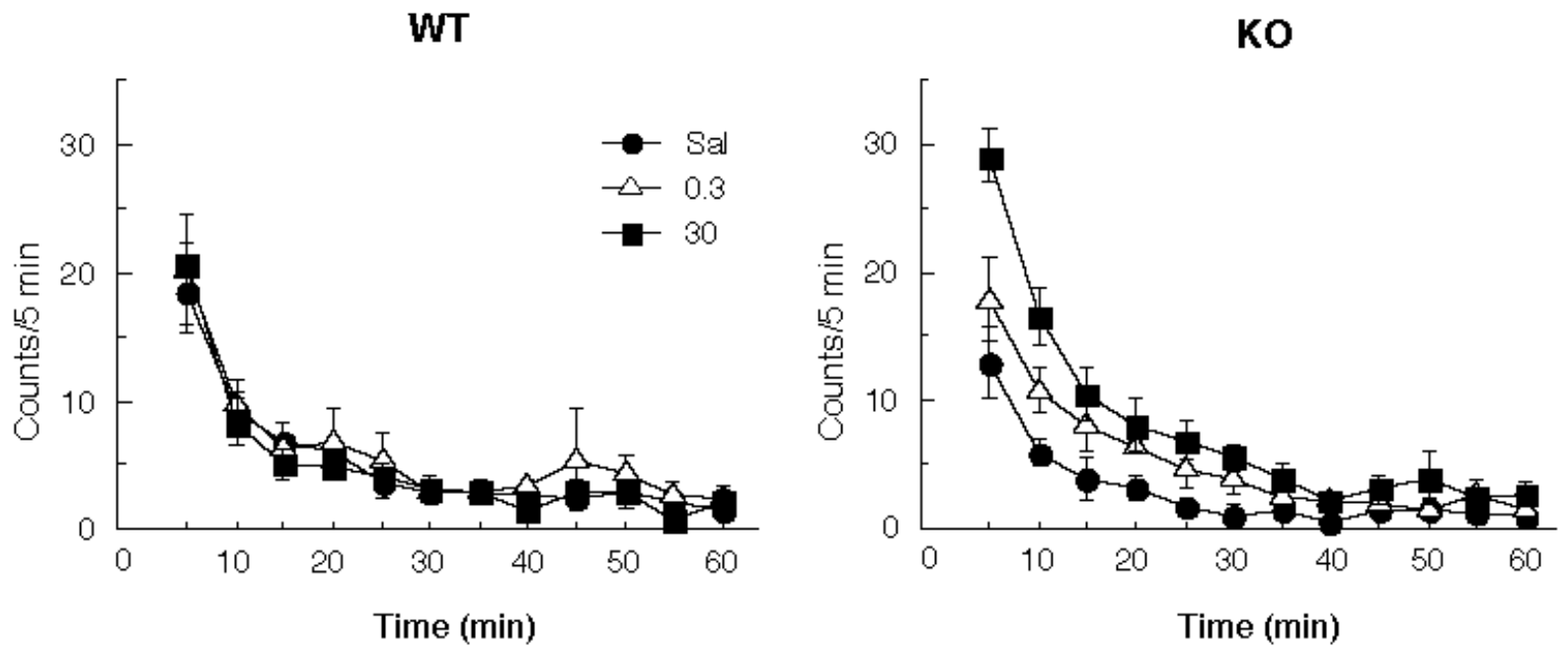

B Dose-response curve

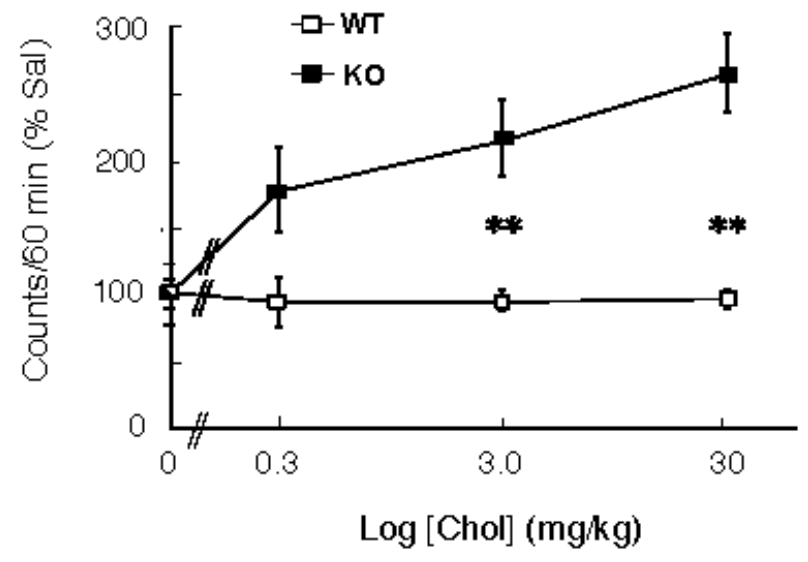

Figure 3 

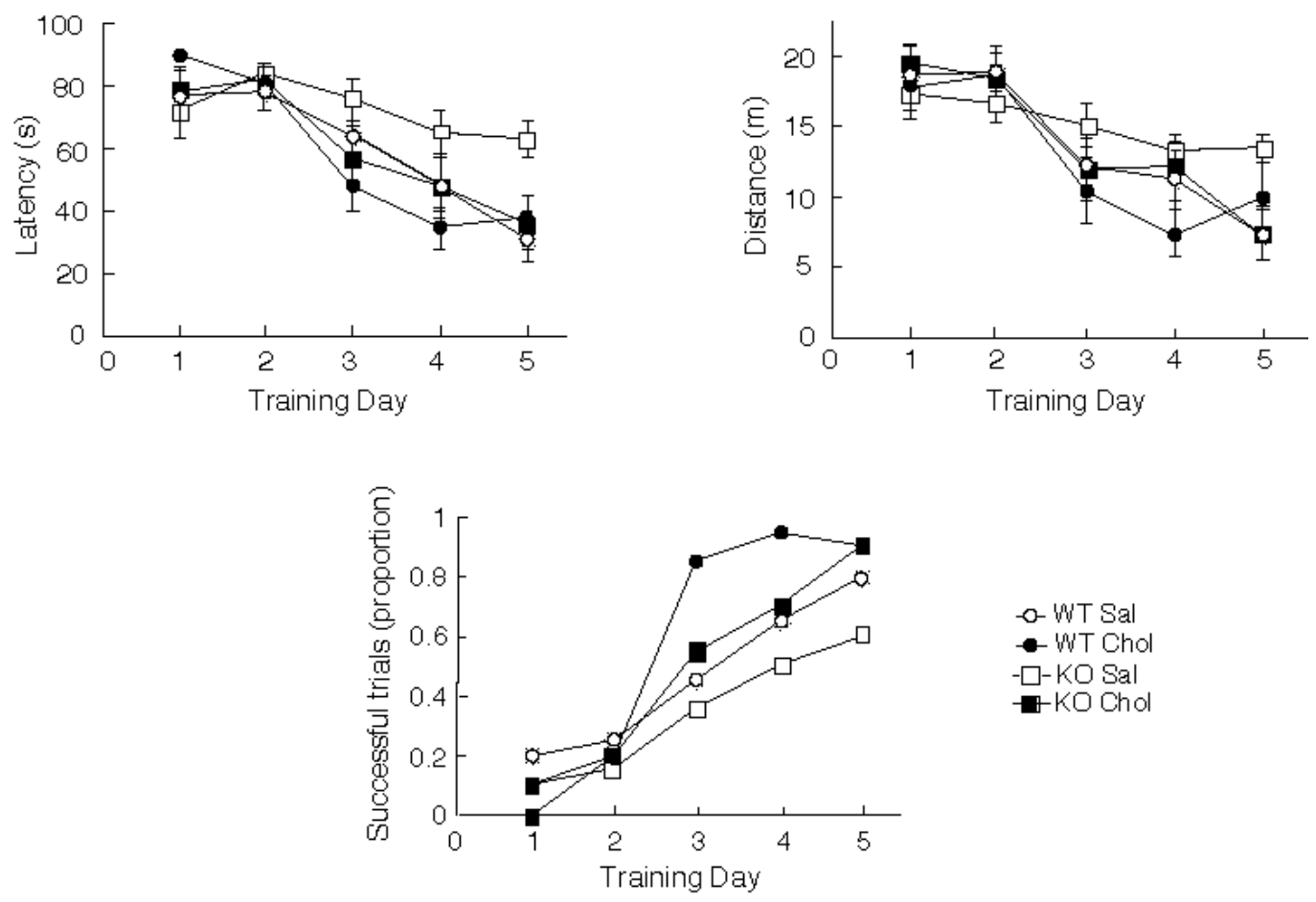

Figure 4 